\title{
SELECTIVITY OF INSECTICIDES TO Encarsia hispida (Hymenoptera: Aphelinidae) ${ }^{1}$
}

\author{
ROBÉRIO DE OLIVEIRA ${ }^{2 *}$, MILENY DOS SANTOS DE SOUZA², GILMAR DA SILVA NUNES ${ }^{3}$, JACINTO DE \\ LUNA BATISTA ${ }^{4}$, CARLOS HENRIQUE DE BRITO 5
}

\begin{abstract}
The use of non-selective insecticides in agricultural production can reduce or eliminate biological agents that regulate insects that are undesirable to humans in production processes. Here, the toxicity of synthetic products on the parasitoid Encarsia hispida was evaluated, the host of which is the whitefly, Bemisia tabaci biotype B, found on cotton plants. The study was carried out using bioassays, in a completely randomized design in a factorial scheme. Pupae and adults of E. hispida were used in the bioassays, which had been sprayed with various chemicals (thiamethoxam, deltamethrin, imidacloprid, and pyriproxyfen) at different concentrations $\left(1.0 \mathrm{~g} \mathrm{~L}^{-1}, 1.0 \mathrm{~mL} \mathrm{~L}^{-1}, 4.0 \mathrm{~mL} \mathrm{~L}^{-1}\right.$, and $\left.2.5 \mathrm{~mL} \mathrm{~L}^{-1}\right)$. The control treatment was distilled water. Chemicals were topically placed in the dorsal region of the tegument of 1 and 3-day old pupae. Then, between 1 and 15-days of emergence of adult parasitoids, residual contact bioassay were used to determine the toxicity of the insecticides. The insecticides thiamethoxam and imidacloprid were harmless to the pupal stage of $E$. hispida, but were harmful to the adult stage. The insecticides deltamethrin and pyriproxyfen were harmful to both pupal and adult stages of E. hispida.
\end{abstract}

Keywords: Gossypium hirsutum. Whitefly. Parasitoid. Pesticides.

\section{SELETIVIDADE DE INSETICIDAS A Encarsia hispida (Hymenoptera: Aphelinidae)}

RESUMO - O uso de inseticidas não seletivos na produção agrícola pode reduzir ou eliminar agentes biológicos que regulam os insetos indesejáveis para o homem no processo produtivo. Neste estudo, o efeito da toxicidade de produtos sintéticos foi avaliado para o parasitoide Encarsia hispida tendo como hospedeiro a mosca-branca, Bemisia tabaci biótipo B, em algodoeiro. O estudo foi realizado através do uso de bioensaios, usando-se delineamento inteiramente casualizado em esquema fatorial. Nos bioensaios foram utilizadas pupas e adultos de E. hispida, as quais foram submetidas à pulverização com os seguintes produtos químicos: tiametoxam, deltametrina, imidacloprido e piriproxifem, nas proporções de $1,0 \mathrm{~g} \mathrm{~L}^{-1}, 1,0 \mathrm{~mL} \mathrm{~L}^{-1}, 4,0 \mathrm{~mL} \mathrm{~L}^{-1} \mathrm{e}$ $2,5 \mathrm{~mL} \mathrm{~L}^{-1}$, respectivamente, e um tratamento controle (água destilada). Foram utilizadas pupas com 1 e 3 dias de idade para exposição tópica, mediante aplicação na região dorsal do tegumento. Nos adultos do parasitoide, com idade de 1 e 15 dias de emergência, foram utilizados um bioensaio de contato residual para determinação da toxicidade dos inseticidas. Os inseticidas tiametoxam e imidacloprido são inócuos ao estágio de pupa, no entanto, os mesmos são nocivos à fase adulta de E. hispida. Os inseticidas deltametrina e piriproxifem são nocivos para ambas fases pupal e adulta de E. hispida.

Palavras-chave: Gossypium hirsutum. Mosca-branca. Parasitoide. Agrotóxicos.

\footnotetext{
*Corresponding author

${ }^{1}$ Received for publication in $08 / 15 / 2018$; accepted in $12 / 20 / 2018$.

Extracted from the first author's Doctor's thesis.

${ }^{2}$ Universidade Federal da Paraíba, Areia, PB, Brazil; roberio_b19@yahoo.com.br - ORCID: 0000-0002-4590-9934, mileny.lopes67@gmail.com - ORCID: 0000-0003-0601-7295.

${ }^{3}$ Universidade Estadual Paulista, Jaboticabal, SP, Brazil; gilmarsilvanunes@gmail.com - ORCID: 0000-0002-8310-1987.

${ }^{4}$ Departament of Plant Science and Environmental Sciences, Universidade Federal da Paraíba, Areia, PB, Brazil; jacinto@cca.ufpb.br ORCID: 0000-0001-8860-8085.

${ }^{5}$ Departament of Biological Sciences, Universidade Federal da Paraíba, Areia, PB, Brazil; carlos@cca.ufpb.br - ORCID: 0000-0002-01950986 .
} 


\section{INTRODUCTION}

The cultivation of cotton Gossypium hirsutum L. var. latifolium Hutch is an economically important agribusiness in Brazil, with major technological investments to enhance productive efficiency (OLIVEIRA et al., 2012). However, the insect pests of cotton plants change in response to changing climatic conditions, causing significant losses to agricultural production (LEITE et al., 2010). The behavior and biology of insects have various attributes allowing them to adapt and build resistance to various conditions, including a short life cycle, high fertility, and high capacity of dispersion. One such example of an insect pest on cotton is the whitefly Bemisia tabaci Gennadius (PRABHAKER; TOSCANO; HENNEBERRY, 1998; BONATO et al., 2007).

Through applying insecticide products to control of Bemisia spp. worldwide, this pest corresponds to a complex of at least 34 morphologically indistinct species (DE BARRO et al., 2011; AHMED et al., 2013). Insecticides also negatively affect the survival of beneficial arthropods. Diamantino et al. (2014) evaluated the selectivity of synthetic products on parasitoids in the cotton plant cultivar DeltaOpal in the southwest of Bahia State, Brazil. The authors found that mortality caused by a variety of products (Fipronil $^{\circledR} 200$ SC, Alfacipermetrina $100 \mathrm{SC}$, Lufenuron ${ }^{\circledR} 50 \mathrm{EC}$, Imidacloprid $^{\circledR} 200 \mathrm{SC}$, and Parathion methyl ${ }^{\circledR} 600$ EC) was accentuated in different applications of pesticide. However, following the third application of pesticides, just $26 \%$ of the beneficial biological agents survived.

The incorporation of selective insecticides in Integrated Pest Management (IPM) could minimize the deleterious effects of chemical control on nontarget organisms (FERREIRA et al., 2006). Among natural enemies, the parasitoid Encarsia hispida De Santis has been reported to regulate populations of $B$. tabaci biotype B and the whitefly Trialeurodes vaporariorum Westwood naturally on crops of cotton, tobacco, tomato, soybean, cabbage, beans, melons, and eggplant in the midwest region of the Brazilian territory (OLIVEIRA et al., 2003). In the northeast region of Brazil, E. hispida was documented parasitizing the whitefly Trialeurodes variabilis Quaintance on papaya crops (LOURENÇÃO et al., 2007), with high parasitism potential on B. tabaci biotype B hosts in cotton cultivars (OLIVEIRA et al., 2016).

Pedigo and Rice (2009) support the need for control tactics, such as the use of natural enemies and resistant plants, to minimize attacks by pests in IPM. Thus, this study aimed to analyze the toxicity of insecticides to the parasitoid E. hispida that has $B$. tabaci biotype $\mathrm{B}$ as its host on two cotton cultivars

\section{MATERIAL AND METHODS}

The study was carried out in the Laboratory of Entomology (LEN), Campus II of the Federal University of Paraíba (UFPB), Areia, Paraíba State, Brazil. The experiment was performed under laboratory conditions, at $25 \pm 2{ }^{\circ} \mathrm{C}$ temperature, $70 \pm$ $10 \%$ relative humidity (R.H.) and a $12 \mathrm{~h}$ photophase.

\section{Rearing of whitefly and parasitoid}

Populations of both the whitefly $B$. tabaci biotype $\mathrm{B}$ and the parasitoid E. hispida were reared in the LEN, using the methodology proposed by Oliveira et al. (2016) in a greenhouse and laboratory, respectively. We used the cotton cultivars BRS H8 (white) and BRS Topázio (brown) from the National Cotton Research Center of the Brazilian Agricultural Research Corporation (EMBRAPA/CNPA).

The adults of the parasitoids were collected using gelatin capsules 00 Medeiros (2009). After capture, the adults were released next to plants of Euphorbia pulcherrima Wild to be colonized containing nymphs of 3 rd and 4 th instars of $B$. tabaci.

\section{Mortality rate of $E$. hispida pupae}

Leaves of both cotton cultivars BRS H8 and BRS Topázio containing pre-pupae of E. hispida were collected from the LEN greenhouse and were posteriorly removed using an entomological pin that was placed in Petri dishes $(15.0 \times 2.0 \mathrm{~cm})$ until they reached the pupal stage. We used 1 and 3-day old parasitoids.

We used a completely randomized design in a factorial scheme $(2 \times 5)(1$ and 3 day-old pupae $\times$ five chemical products) for each cotton cultivar, and with four replications. We used the following treatments: (Actara $\left.{ }^{\mathbb{B}} 250 \mathrm{WG}\right)$, deltamethrin (Decis ${ }^{\mathbb{B}}$ EC), imidacloprid (Proven $^{\circledR} 200$ SC), and pyriproxyfen $\left(\right.$ Tiger $\left.^{\circledR} 100 \mathrm{EC}\right)$ at concentrations of $1.0 \mathrm{~g} \mathrm{~L}^{-1}, 1.0 \mathrm{~mL} \mathrm{~L}^{-1}, 4.0 \mathrm{~mL} \mathrm{~L}^{-1}$, and $2.5 \mathrm{~mL} \mathrm{~L}^{-1}$. The control treatment used distilled water. The experimental unit consisted of 25 pupae placed in Petri dishes $(9.0 \times 1.5 \mathrm{~cm})$ containing filter paper. In the pupae, the chemicals were applied topically by manually spraying their entire integument of the pupae. Then, the recipients were arranged in an airy atmosphere and covered with plastic film. The environmental conditions were $26 \pm 2{ }^{\circ} \mathrm{C}, 70 \pm 10 \%$ R.H., and $12 \mathrm{~h}$ photo-phase.

Five days after the pupae were exposed to the treatments, we recorded the mortality of the parasitoid for the two evaluated ages, viz., days 1 and 3. 


\section{Mortality rate of adult $E$. hispida}

For the bioassay, the leaves of both cotton cultivars containing pupae of E. hispida were collected and transferred to the laboratory. Within 12 $\mathrm{h}$ of the parasitoids emerging, they were collected in gelatin capsules 00 (MEDEIROS, 2009) and subjected to the residual contact method proposed by Ozawa, Saito and Ikeda (1998) to determine the mortality rate of the insect. The same insecticides were used for the adult stage of the parasitoid, diluted in acetone (99.5\%). Then, an aliquot of 2.5 $\mathrm{mL} \mathrm{L}^{-1}$ was placed in a test tube $(8.5 \times 1.5 \mathrm{~cm})$ so that it spread in the container, and remained in the ventilated environment for $1 \mathrm{~h}$ to eliminate the diluent. For the control, we used only the spreader. Thus, the experimental unit consisted of 10 insects placed in containers with honey as food. The test tubes were sealed with a micro-perforated plastic film.

After $24 \mathrm{~h}$ of parasitoids being exposed to the insecticides, mortality was recorded using a stereoscopic magnifying glass. The experimental conditions were: $26 \pm 2{ }^{\circ} \mathrm{C}, 70 \pm 10 \%$ R.H., and a 12 $\mathrm{h}$ photo-phase. The experimental design was completely randomized a in factorial scheme $(2 \times 5)$ (adult of 1 and 15-days old $x$ five chemical products) for each cultivar, and with four replications.

\section{Statistical Analysis}

Mortality (\%) was initially corrected for in relation to the mortality recorded in the control, using the formula $\mathrm{Ma}=[(\mathrm{Mt}-\mathrm{Mc}) /(100-\mathrm{Mt})] \times 100$, where $\mathrm{Ma}=$ mortality corrected for based on the control treatment; $\mathrm{Mt}=$ mortality observed in the pesticide treatments, and $\mathrm{Mc}=$ mortality observed in the control treatment (ABBOTT, 1925). Then, the data were subjected to analysis of variance, and the means were compared by Student-Newman-Keuls test $(\mathrm{p}<0.05)$ using Assistat 7.7 program (SILVA; AZEVEDO, 2002).

The insecticides were classified into four categories according to the recommended standards of "International Organization for Biological and Integrated control of Noxious Animals and Plants" (IOBC). Specifically, Class 1 - harmless $(<30 \%)$; class 2 - slightly harmful $(30-79 \%)$; class 3 - moderately harmful (80-99\%); and class 4 harmful (>99\%) (AMANO; HASEEB, 2001).

\section{RESULTS AND DISCUSSION}

The insecticides used in this study clearly affected the pupae of E. hispida on both cotton cultivars (Table 1). Thiamethoxam and imidacloprid were harmless (class 1) to the pupal stage in the cultivar BRS $\mathrm{H} 8$ for both evaluated periods. In comparison, deltamethrin and pyriproxyfen significantly affected the pupae, and were classified as harmful (class 4) and moderately harmful (class 3 ) for 1 and 3-day old pupae, respectively. We obtained the same results for the cultivar BRS Topázio. Different deleterious effects in the pupal stage were evidenced because deltamethrin was harmful to the parasitoid. The observed deleterious effects were: 1) lack of viability of pupae, 2) death of adults on emergence, and 3) certain behavioral characteristics, such as tremors and lack of motor coordination in adults after emergence.

Table 1. Mortality (\%) of the pupal stage of Encarsia hispida (mean* $\left.\pm \mathrm{SE}^{*}\right) 5$ days after insecticides were applied to Bemisia tabaci biotype B on two cotton cultivars.

\begin{tabular}{ccccc}
\hline \multirow{2}{*}{ Treatment } & \multicolumn{4}{c}{ Cotton cultivar BRS H8 } \\
\cline { 2 - 5 } & 1 day** & C*** & 3 days** & $\mathrm{C}^{* * *}$ \\
\hline Thiamethoxam & $15.0 \pm 3.14 \mathrm{bA}$ & 1 & $3.0 \pm 1.96 \mathrm{bcB}$ & 1 \\
Deltamethrin & $7.0 \pm 0.00 \mathrm{aA}$ & 4 & $90.0 \pm 3.01 \mathrm{aB}$ & 3 \\
Imidacloprid & $100.0 \pm 0.00 \mathrm{aA}$ & 4 & $8.0 \pm 2.72 \mathrm{bA}$ & 1 \\
Pyriproxyfen & $0.0 \pm 0.00 \mathrm{dA}$ & - & $94.0 \pm 2.38 \mathrm{aB}$ & 3 \\
Control & & Cotton cultivar BRS Topázio & - \\
\hline & $12.0 \pm 3.26 \mathrm{bA}$ & 1 & $18.0 \pm 3.14 \mathrm{cA}$ & 1 \\
\hline Thiamethoxam & $100.0 \pm 0.00 \mathrm{aA}$ & 4 & $85.0 \pm 4.76 \mathrm{bB}$ & 3 \\
Deltamethrin & $9.0 \pm 2.87 \mathrm{bA}$ & 1 & $4.0 \pm 1.96 \mathrm{dA}$ & 3 \\
Imidacloprid & $100.0 \pm 0.00 \mathrm{aA}$ & 4 & $98.0 \pm 1.40 \mathrm{aA}$ & - \\
Pyriproxyfen & $0.0 \pm 0.00 \mathrm{cA}$ & - & $0.0 \pm 0.00 \mathrm{dA}$ & 3 \\
Control &
\end{tabular}

${ }^{*}=$ Averages followed by the same lowercase letter in columns and uppercase letter in rows did not differ when using the Student-Newman-Keuls test $(\mathrm{p}<0.05) ;{ }^{* *}=$ Day $(\mathrm{s})-$ age of the pupae; ${ }^{* * *}=$ Class $1-$ harmless $(<30 \%)$, Class 2 - slightly harmful (30-79\%), Class 3 - moderately harmful (80-99\%), Class 4 - harmful (>99\%).

The presence of residues of deltamethrin in the tegument of the parasitoid pupae caused the adults to die on emergence, possibly harming the pupae too. This product clearly affected the nervous system of the insect. According to Spencer et al. (2001), insecticides interfere with the opening and closing of neural sodium channels, extending the time that $\mathrm{Na}^{+}$enter, which results in the transmission 
of repetitive and uncontrolled impulses, hyperexcitability, loss of locomotor posture ("Knockdown"), and, probably, paralysis and death. This insecticide was also statistically different in the analyzed periods for both cultivars with 3-day old individuals; however, the mechanisms were not known.

The insecticides deltamethrin and pyriproxyfen were highly toxic before parasitoids emerged for both cotton cultivars. However, there were survivors when these insecticides were applied on 3-day old pupae. The compounds of juvenile hormones, or similar hormones, might act through different connections between cells and proteins (DHADIALLA; CARLSON; LE, 1998). Thus, the mortality of pupae by the insecticide pyriproxyfen might be linked to its mode of action. This mode of action might affect the hormonal balance of insects when applied, interfering with the metamorphosis process, inhibiting juvenile hormone, resulting in the insect not being viable, leading to death.

We found that pyriproxyfen had no statistically different effect on 1 and 3-day old pupae in the cultivar BRS H8. The non-suppression of individuals (pupae) at these ages might be related to their tegument being more developed, preventing the insecticide from penetrating the insect.

Thiamethoxam and imidacloprid might have been harmless to the pupae of the parasitoid because the compounds could not penetrate the exuviae of the host (whitefly), which served as a mechanical barrier (i.e., the parasitoid had no direct contact with these products). The parasitoid did not emerge from its cocoon in one case, possibly because of the effects of insecticide residues when the parasitoid opened the cocoon during emergence, leading to death. These effects occurred because the insecticides penetrated structures called blowholes at the time of emergence and/or orally when the cocoon was opened during emergence. Acetylcholine is the main neurotransmitter in the central nervous system (CNS) of insects. Its action is modulated by the enzyme acetylcholinesterase (AChE), which interrupts the transmission of nerve impulses through the hydrolysis of acetylcholine in acetate and choline (NAUEN et al., 2001).

The results of the present study regarding thiamethoxam differed to those of Vieira et al. (2012). The authors tested the selectivity of insecticides on 7-day old pupae of the parasitoid Encarsia formosa Gahan, showing that the chemicals thiamethoxam 25 and thiamethoxam 50 (neonicotinoid chemical group) caused significant mortality to the parasitoid. As a result, they classified these two chemicals as slightly harmful (class 2) and moderately harmful (class 3), respectively. The authors suggested that the insecticide piriproxifem was moderately harmful to the pupal stage of the biological agent, which was supported by the results of the present study when using 3-day old pupae.

A previous study showed that $0.05 \mathrm{~mL} \mathrm{~L}^{-1}$ and $1.0 \mathrm{~mL} \mathrm{~L}^{-1}$ concentrations of piriproxifem reduced the emergence of $E$. formosa pupae by $44.6 \%$ and $73.5 \%$ (LIU; STANSLY, 1997). This result contrasted with the current study, in which this compound eliminated from $94 \%$ to $100 \%$ of $E$. hispida pupae. Liu and Stansly (1997) observed that $40 \%$ of adults that emerged from pupae had deformed wings, affecting flight, when $1.0 \mathrm{~g} \mathrm{~L}^{-1}$ of the compound was used. The parasitoids showed typical behavior in relation to the location of the host habitat, host selection, host acceptance, host adequacy, and oviposition.

With respect to imidacloprid, the results of the current study on E. hispida pupae contrast with those of Sugiyama, Katayama and Saito et al. (2011). The authors classified this compound as slightly harmful to both the pupae and adults of E. formosa. We verified that the product was applied to the pupal stage of E. hispida at both ages according to the International Organization for Biological and Integrated control of Noxious Animals and Plants classification, thus making it possible to use it to regulate the $B$. tabaci biotype $\mathrm{B}$.

All insecticides were classified as harmful to E. hispida adults reared on both cotton cultivars, except for the 15-day-old adults exposed to pyriproxyfen on both cultivars (Table 2). We verified that the insecticides from different chemical groups (i.e., neonicotinoids, pyrethroids, and pyridyl oxy ether) affect the parasitoid, regardless of the mode of action of the chemical. The insecticides from two of these groups (neonicotinoids and pyrethroids) eliminated the parasitoids in less than 2 $\mathrm{h}$ after exposure to the environment with chemical residues. Therefore, the insecticides probably penetrated the body of the insect, depending on the thickness and chemical composition of the cuticle. In general, lipophilic compounds usually penetrate the insect body at higher rates (LEITE et al., 1998). 
Table 2. Mortality (\%) of the adult stage of Encarsia hispida (mean* $\pm \mathrm{SE}^{*}$ ) one day after insecticides were applied to the host, Bemisia tabaci biotype B, on two cotton cultivars.

\begin{tabular}{ccccc}
\hline \multirow{2}{*}{ Treatment } & \multicolumn{4}{c}{ Cotton cultivar BRS H8 } \\
\cline { 2 - 5 } & \multicolumn{1}{c}{1 day** } & $\mathrm{C}^{* * *}$ & 15 days** & $\mathrm{C}^{* * *}$ \\
\hline Thiamethoxam & $100.0 \pm 0.00 \mathrm{aA}$ & 4 & $100.0 \pm 0.00 \mathrm{aA}$ & 4 \\
Deltamethrin & $100.0 \pm 0.00 \mathrm{aA}$ & 4 & $100.0 \pm 0.00 \mathrm{aA}$ & 4 \\
Imidacloprid & $100.0 \pm 0.00 \mathrm{aA}$ & 4 & $100.0 \pm 0.00 \mathrm{aA}$ & 4 \\
Pyriproxyfen & $100.0 \pm 0.00 \mathrm{aA}$ & 4 & $91.6 \pm 3.59 \mathrm{bB}$ & 3 \\
Control & $0.0 \pm 0.00 \mathrm{bA}$ & - & $0.0 \pm 0.00 \mathrm{cA}$ & - \\
\hline & & Cotton cultivar BRS Topázio & 4 \\
\hline Thiamethoxam & $100.0 \pm 0.00 \mathrm{aA}$ & 4 & $100.0 \pm 0.00 \mathrm{aA}$ & 4 \\
Deltamethrin & $100.0 \pm 0.00 \mathrm{aA}$ & 4 & $100.0 \pm 0.00 \mathrm{aA}$ & 3 \\
Imidacloprid & $100.0 \pm 0.00 \mathrm{aA}$ & 4 & $100.0 \pm 0.00 \mathrm{aA}$ & - \\
Pyriproxyfen & $100.0 \pm 0.00 \mathrm{aA}$ & 4 & $93.3 \pm 0.03 \mathrm{bB}$ & $0.0 \pm 0.00 \mathrm{cA}$ \\
Control & $0.0 \pm 0.00 \mathrm{bA}$ & - &
\end{tabular}

${ }^{*}=$ Averages followed by the same lowercase letter in columns and uppercase letter in rows did not differ when using the Student-Newman-Keuls test $(\mathrm{p}<0.05) ;{ }^{* *}=$ Day $(\mathrm{s})$ - age of the pupae; ${ }^{* * *}=$ Class $1-$ harmless $(<30 \%)$, Class 2 - slightly harmful (30-79\%), Class 3 - moderately harmful (80-99\%), Class 4 - harmful (>99\%).

\section{CONCLUSIONS}

The insecticides thiamethoxam and imidacloprid are harmless to the pupal stage of $E$. hispida but are harmful to the adult stage.

The insecticides deltamethrin and pyriproxyfen are harmful to both the pupal and adult stages of E. hispida.

\section{ACKNOWLEDGMENTS}

The authors thank to Dra. Roseli Pessoa of the Universidade Estadual "Júlio de Mesquita Filho", Jaboticabal - SP, Brazil, and to Dr. Valmir Antonio Costa do Instituto Biológico of the Laboratory of Biological Control, of Campinas - SP, Brazil, for identifying the parasitoid. The authors also thank Coordenação de Aperfeiçoamento de Pessoal de Nível Superior (CAPES), for granting scholarships.

\section{REFERENCES}

ABBOTT, W. S. A method of computing the effectiveness of an insecticide. Journal of Economic Entomology, v. 18, n. 2, p. 265-267, 1925.

AHMED, M. Z. et al. Evidence for horizontal transmission of secondary endosymbionts in the Bemisia tabaci cryptic species complex. PLoS ONE, v. 8, n. 1, p. 53-84, 2013.

AMANO, H.; HASEEB, M. Recently-proposed methods and concepts of testing the effects of pesticides on the beneficial mite and insect species: study limitations and implications in IPM. Applied Entomology and Zoology, v. 36, n. 1, p. 1-11, 2001.

BONATO, $\mathrm{O}$. et al. Modelling temperature- dependent bionomics of Bemisia tabaci (Q-biotype). Physiological Entomology, v. 32, n. 1, p. 50-55, 2007.

DE BARRO, P. J. et al. Bemisia tabaci: a statement of species status. Annual Review of Phytopathology, v. 56, n. 1, p. 1-19, 2011.

DHADIALLA, T. S.; CARLSON, G. R.; LE, D. P. New insecticides with ecdysteroidal and juvenile hormone activity. Annual Review of Entomology, v. 43, n. 1, p. 545-569, 1998.

DIAMANTINO, E. $P$. et al. Seletividade de inseticidas a alguns dos inimigos naturais na cultura do algodão. Arquivos do Instituto Biológico, v. 81, n. 2 , p. $150-158,2014$.

FERREIRA, A. J. et al. Seletividade de inseticidas usados na cultura da macieira a duas populações de Chrysoperla externa (Hagen, 1861) (Neuroptera: Chrysopidae). Revista Ciência Rural, v. 36, n. 2, p. 378-384, 2006.

LEITE, G. L. D. et al. Selectivity of insecticides with and without mineral oil to Brachygastra lecheguana (Hymenoptera: Vespidae), a predator of Tuta absoluta (Lepidoptera: Gelechiidae). Ceiba, v. 39, n. 1, p. 191-194, 1998.

LEITE, M. I. S. et al. Ação residual de inseticidas para larvas e adultos do predador Cycloneda sanguinea Linnaeus, 1763 (Coleoptera: Coccinellidae). Arquivos do Instituto Biológico, v. 77, n. 2, p. 275-282, 2010.

LIU, T. X.; STANSLY, P. A. Effects of pyriproxyfen on three species of Encarsia (Hymenoptera: Aphelinidae), endoparasitoids of Bemisia argentifolii (Homoptera: Aleyrodidae). 
Journal of Economic Entomology, v. 90, n. 2, p. 404-411, 1997.

LOURENÇÃO, A. L. et al. Parasitismo em Trialeurodes variabilis (Quaintance) (Hemiptera: Aleyrodidae) por Encarsia hispida De Santis (Hymenoptera: Aphelinidae), em mamoeiro, no Brasil. Neotropical Entomology, v. 36, n. 1, p. 147149, 2007.

MEDEIROS, M. A. Parasitismo natural em ovos crisopídeos. Ciência Rural, v. 39, n. 1, p. 221-223, 2009.

NAUEN, R. et al. Acetylcholine receptors as sites for developing neonicotinoid insecticides. In: ISHAAYA, I. (Ed.). Biochemical sites of insecticide action and resistance. Berlin: SPRINGER, 2001, s/v., cap. 4, p. 77-105.

OLIVEIRA, F. A. et al. Sensibilidade do algodoeiro ao cloreto de mepiquat em condições salinas. Revista Ciência Agronômica, v. 43, n. 3, p. 484492, 2012.

OLIVEIRA, M. R. V. et al. Natural enemies of Bemisia tabaci (Gennadius) B biotype and Trialeurodes vaporariorum (Westwood) (Hemiptera: Aleyrodidae) in Brasília, Brazil. Neotropical Entomology, v. 32, n. 1, p. 151-154, 2003.

OLIVEIRA, R. et al. Development and parasitism of Encarsia hispida (Hymenoptera: Aphelinidae) on Bemisia tabaci biotype B in cotton. African Journal of Agricultural Research, v. 11, n. 26, p. 2266$2270,2016$.

OZAWA, A.; SAITO, T.; IKEDA, F. Effects of pesticides on Diglyphus isaea (Walker) and Dacnusa sibirica Telenga, parasitoids of Liriomyza trifolii (Burgess). Japanese Journal of Applied Entomology and Zoology, v. 42, n. 3, p. 149-161, 1998.

PEDIGO, L. P.; RICE, M. E. Entomology and pest management. 6 . ed. Englewood Cliffs, NJ: PRENTICE HALL, 2009. 688 p.

PRABHAKER, N.; TOSCANO, N. C.; HENNEBERRY, T. J. Evaluation of insecticide rotations and mixtures as resistance management strategies for Bemisia argentifolii (Homoptera: Aleyrodidae). Journal of Economic Entomology, v. 91, n. 4 , p. 820-826, 1998.

SILVA, F. A. S.; AZEVEDO, C. A. V. Versão do programa computacional assistat para o sistema operacional windows. Revista Brasileira de
Produtos Agroindustriais, v. 4, n. 1, p. 71-78, 2002.

SUGIYAMA, K.; KATAYAMA, H.; SAITO, T. Effect of insecticides on the mortalities of three whitefly parasitoid species, Eretmocerus mundus, Eretmocerus eremicus and Encarsia formosa (Hymenoptera: Aphelinidae). Applied Entomology and Zoology, v. 46, n. 3, p. 311-317, 2011.

SPENCER, C. I. et al. Actions of pyrethroid insecticides on sodium currents, action potentials, and contractile rhythm in isolated mammalian ventricular myocytes and perfused hearts. The Journal of Pharmacology and Experimental Therapeutics, v. 298, n. 3, p. 1067-1082, 2001.

VIEIRA, S. S. et al. Efeitos dos inseticidas utilizados no controle de Bemisia tabaci (Gennadius) biótipo B e sua seletividade aos inimigos naturais na cultura da soja. Semina: Ciências Agrárias, v. 33, n. 5, p. 1809-1818, 2012. 